\title{
Mål for sosial ulikhet Teoretiske og empiriske vurderinger
}

\author{
Annett Arntzen \\ Avdeling for samfunnsfag/HENER-senteret, Høgskolen i Vestfold, Pb 2243, 3103 Tønsberg \\ Telefon: 33031201 Telefax: 33031105 e-post: Annett.Arntzen@hive.no
}

\begin{abstract}
SAMMENDRAG
Det er ulike valg en står ovenfor når klassebegrepet skal operasjonaliseres. Hvert av valgene innebærer både teoretiske og empiriske vurderinger. For det første, hvilken basis skal klasseanalysen ha, skal klassebegrepet baseres på sosial klasse eller på yrkesklasse? For det andre, hva er passende enheter å inkludere i analysen individet, familien eller husholdet? For det tredje, hvem skal inkluderes i analysen - skal økonomisk inaktive personer ekskluderes? Betraktninger rundt disse valgene og konsekvensene av dem belyses i denne artikkelen.
\end{abstract}

\section{Arntzen A. Operationalisation of class. Theoretical and empirical considerations. Nor J Epidemiol 2002; 12 (1): 11-17.}

\section{ENGLISH SUMMARY}

Different interrelated choices must be taken into consideration in the operationalisation of class. All the choices have both theoretical and empirical elements. First, researchers must choose which conceptual scheme to employ - conventional occupational class or neo-Marxist social class categories? Second, what is to be the unit of analysis - the respondent or the household? Third, what is to be the degree of coverage - whether or not to include the economically inactive? This article is about some issues surrounding these choices.

\section{INNLEDNING}

Epidemiologi er basisdisiplinen i forebyggende medisin og en av de viktigste vitenskapsretningene i generelt folkehelsearbeid. Sosialepidemiologien arbeider med de deskriptive, forklarende og interventive aspektene ved sosiale faktorers betydning for helse, sykelighet og dødelighet. De begrepsmessige og metodologiske målene som benyttes er ofte hentet fra sosiologi eller subdisiplinen medisinsk sosiologi.

I sosiologiske studier er ofte det å forstå og forklare det sosiale hierarkiet $i$ et samfunn eller en gruppe et mål i seg selv. I epidemiologiske studier brukes sosial klasse oftest som en forklaringsfaktor i analyser av andre avhengige variabler, for eksempel om det finnes sosiale risikogrupper for spedbarnsdødelighet. Epidemiologene vurderer sosial klasse til å være en potensiell confounder, en risikofaktor eller en variabel som beskriver utvalget. Uansett om det er variablene yrke, utdanning, inntekt eller kombinasjoner som benyttes, brukes benevnelsen sosial klasse. Det er imidlertid all grunn til å bli mer oppmerksom på de varierende målenes anvendelighet og gyldighet, og bli litt mer reflektert på begrepsbruken av sosial klasse. En økt forståelse av dette vil ikke minst være til god hjelp i fortolkningen av funnene i epidemiologiske studier.
Denne artikkelen handler om fagdebatten rundt operasjonaliseringen av klassebegrepet, og om de teoretiske og empiriske vurderinger som bør knyttes til dette.

\section{DEBATTEN OM KLASSEANALYSE}

Den internasjonale fagdebatten om ulike perspektiver på klasseanalyse har pågått $\mathrm{i}$ en lang periode. Det er to diskusjoner som foregår. Den ene diskuterer relevansen av klasseanalyse i dagens postindustrielle samfunn. Den andre debatten foregår blant de som er enige $i$ at klasseanalyse fortsatt er viktig, men som er uenig $i$ hvordan klassebegrepet både teoretisk og empirisk bør konseptualiseres.

\section{Er klasseanalyse relevant i dagens samfunn?}

Den første debatten dreier seg først og fremst om relevansen av klasseteori for å forstå de sosiale endringsprosessene som moderne samfunn har gjennomgått, og konsekvensene av dem. Kritikerne hevder at klassebegrepet har lite å tilføre samfunnsvitenskapelig forskning i dag fordi vi i den vestlige del av verden lever i samfunn uten klare klasseskiller i befolkningen, den manuelle arbeiderklassen avtar relativt sett i størrelse samtidig som den nye middelklassen har vokst frem, 
skillet mellom arbeid og kapital og eiere og ikke-eiere av produksjonsmidler er diffust, og yrkesstrukturen preges nå av spesialisering og fragmentering. Andre argumenter er at klassestrukturen er blitt mer åpen enn tidligere for sosial mobilitet, og at fremveksten av velferdsstatens universalistiske sikkerhetsnett sikrer alles livsvilkår. Hurtigere teknologisk utvikling, økende konsumorientering, tiltakende globalisering av økonomien, fremveksten av post-materielle verdier, kvinnenes endrede stilling i samfunnet og selvsagt de generelle individualiseringstendensene bidrar også til å transformere de moderne samfunn. For noen samfunnsforskere betyr alt dette at klassene er 'døde', mens for andre - som for eksempel Wright, Goldthorpe, Erikson og Bourdieu - betyr dette inspirasjon til å revurdere tidligere klassebegreper. De har utviklet nye modeller som muligens bedre forstår og forklarer dagens klassesamfunn.

\section{Hvilken teoretiske modell og hvilke empiriske mål skal benyttes i klasseanalysen?}

Den andre fagdebatten dreier seg om hvilken teoretiske modell og hvilke empiriske mål som skal benyttes $i$ analysene. For eksempel om en skal bruke klasseeller lagdelingsanalyse, sosial klasse eller yrkesklasse. Feminister har stimulert denne diskusjonen og fokusert på hvem enhetene i analysen skal være. Variabler som utdanning, inntekt og sosioøkonomisk status kan relateres både til individet og til familien. I tillegg må man vurdere hvem analysen skal omfatte, skal for eksempel økonomisk inaktive personer ekskluderes eller ikke?

\section{OPERASJONALISERINGEN AV KLASSE}

Tabell 1 illustrerer tre viktige valg man står overfor i operasjonaliseringen av klassebegrepet. Avsnittene som følger er strukturert etter hva de ulike valgene innebærer av teoretiske og empiriske vurderinger.
Valg 1. Basis for klasse - teoretiske vurderinger sosial klasse eller yrkesklasse?

Skal klassebegrepet baseres på sosialklasse som relateres til sosiale relasjoner i forhold til produksjonen, eller på yrkesklasse som er basert på en mer teknisk fordeling til produksjonen?

Begrepet klasse blir ofte brukt synonymt med sosioøkonomisk status, sosial tilhørighet, sosial status, sosial posisjon, sosiale lag eller sosial stratifisering. Mange forskere bruker begrepene uten å redegjøre for de ulike teoretiske distinksjonene som ligger til grunn for de ulike benevnelsene. Dermed blir ofte begrepene brukt ureflektert, vekslende og om hverandre. Dette gjør det blant annet vanskelig med komparative studier både i og utenfor landegrensene. Det hevdes imidlertid at klassebegrepet bør reserveres til et mer avgrenset sett av tilnærminger til samfunnsstrukturen.

Klasseteori har to karakteristiske trekk, for det første fokuseres det på relasjonene mellom klassene, og for det andre oppfattes ikke relasjonene som fredelig interaksjon og gjensidig avhengighet, men framfor alt som motsigelser og konflikt. Prototypen på klasseteori bygger på Karl Marx. Marx sitt klassebegrep er et redskap til å tolke samfunnsutviklingen. De samfunnsendringene som er av betydning oppstår som en følge av grunnleggende økonomiske motsetninger mellom klassene, og klassemotsetningene avler uunngåelig klassekamp og en revolusjonær omveltning ifølge Marx. Kapitalismen deler samfunnet $\mathrm{i}$ to atskilte klasser, borgerskapet som eier produksjonsmidlene og proletariatet som kun eier sin arbeidskraft. Det er altså den enkeltes forhold til produksjonsmidlene som er av analytisk betydning, mer enn status- eller inntektsforskjeller. Marx sin to-klassemodell, der man kun opererer med kapitalister og arbeidere, er utilstrekkelig i dagens samfunn. Derfor sliter mange av de nymarxistiske arbeidene med for eksempel å begrepsbestemme den nye middelklassen.

Tabell 1. Tre valg i operasjonaliseringen av klasse - teoretiske og empiriske vurderinger.

\begin{tabular}{|c|c|c|}
\hline Valg & Teoretiske vurderinger & Empiriske vurderinger \\
\hline $\begin{array}{l}\text { 1. Hvilket begreps- } \\
\text { system skal velges? }\end{array}$ & $\begin{array}{l}\text { Sosial klasse } \\
\text { versus } \\
\text { Yrkesklasse }\end{array}$ & $\begin{array}{l}\text { Sosial klasse - f.eks. E.O. Wright } \\
\text { versus } \\
\text { Yrkesklasse - f.eks. yrkesgrupper, prestisje }\end{array}$ \\
\hline $\begin{array}{l}\text { 2. Enhetene i } \\
\text { analysen? }\end{array}$ & $\begin{array}{l}\text { Familien, husholdet } \\
\text { versus } \\
\text { Individet, respondenten }\end{array}$ & $\begin{array}{l}\text { Enkle indikatorer }- \text { f.eks. familiens hovedforsørger, } \\
\text { kombinasjoner eller dominans } \\
\text { versus } \\
\text { Multiple indikatorer }\end{array}$ \\
\hline $\begin{array}{l}\text { 3. Hvem skal inklu- } \\
\text { deres i analysen? }\end{array}$ & $\begin{array}{l}\text { Økonomisk aktive } \\
\text { versus } \\
\text { Både økonomisk aktive og inaktive }\end{array}$ & $\begin{array}{l}\text { Økonomisk aktive - f.eks. heltid og deltid } \\
\text { versus } \\
\text { Økonomisk inaktive - f.eks. samme regler for } \\
\text { arbeidsledige og hjemmeværende }\end{array}$ \\
\hline
\end{tabular}


Hovedformålet med klasseteorien er å identifisere sosiale klasser for å kunne forklare kollektiv handling, sosial konflikt og sosial endring. I den europeiske tradisjon oppfattes klasser som reelt eksisterende størrelser som er definert ved materielle, sosiale og bevissthetsmessige forhold. Klassemedlemmenes sosiale posisjon er også et utgangspunkt for ulikhet i inntekt og velstand, men klassene står $i$ et gjensidig avhengighetsforhold til hverandre og opptrer ikke i atskilte lag.

Når det gjelder lagdelingsteorien legger den liten vekt på relasjonene som knytter grupperingene sammen, men retter oppmerksomheten på hvordan samfunnet er ordnet i et hierarki av strata. Lagdelingsforskningen sammenligner de ulike strata med hensyn til fordelingen av goder. Max Weber så sitt klassebegrep som et alternativ til og en kritikk av Marx sitt klassebegrep. Hans kritikk går på to nivåer. For det første hevder Weber at sosial endring kan frembringes av kulturelle krefter. "Den protestantiske etikk og kapitalismens ånd" representerer en motforestilling mot Marx sin historiske determinisme med utgangspunkt $i$ klassekonflikt. For det andre gikk Weber imot at sosiale klasser bare avgrenses til forhold omkring eiendom av produksjonsmidlene. Folk har ulike sjanser til å få byttet til seg materielle goder gjennom transaksjoner på et marked. Hos Weber baseres derfor klassene på likheter i markedssituasjonen. Gruppene skiller seg fra hverandre på grunn av deres ulike livssjanser.

Ifølge Webers klassiske inndeling er det tre grunnleggende stratifikasjonskriterier: Den økonomiske dimensjonen, som er relatert til vare og arbeidsmarkeder, statusdimensjonen som viser til ære, anseelse og prestisje, og autoritetsdimensjonen som gjelder politisk og annen myndighetsutøvelse. Det er ingen nødvendig eller logisk sammenheng mellom de tre stratifikasjonskriteriene. Hvilken dimensjon som er viktigst er et empirisk spørsmål og vil avhenge av de verdier og normer som dominerer i et samfunn.

Et weberiansk perspektiv på klassebegrepet vil ikke i samme grad som et marxistisk perspektiv være opptatt av klassenes rolle i konflikter og i sosiale endringsprosesser. I et ny-weberiansk perspektiv antas klasseinteressene å være ulike, men ikke antagonistiske slik de er i det marxistiske perspektivet. Weberianere har ikke bestemte generelle forventninger til hvorvidt konfliktmønstre $i$ et samfunn vil være assosiert med klasseskillene. Lagdelingsteoriene fokuserer dermed lite på relasjonene som knytter klassene eller grupperingene sammen.

Hovedformålet med lagdelingsanalysene er å studere og sammenligne grader av ulikhet. Ulikhet oppfattes som noe som har eksistert i alle tider og eksisterer i alle samfunn. Ulikhet har en hierarkisk struktur og den kan rangordnes. Enhetene i analysen kan vilkårlig deles inn i sosiale lag eller strata der hvert lag består av aggregater av mennesker som har omtrent samme andel av et eller flere goder, som for eksempel prestisje, status eller materiell standard.

De grunnleggende teoretiske forskjellene i klasse- og lagdelingsmodellene innebærer altså at man står overfor to potensielt meget forskjellige samfunnsbilder. Selv om både ny-marxister og ny-weberianere har brukt yrker og egenskaper ved yrker til å aggregere klasser er det et klart analytisk skille mellom sosial klasse og yrkesklasse. Yrkesklassene utgjør posisjoner i den sosiale arbeidsdelingen som defineres ut fra deres tekniske funksjoner og aktiviteter, og sosial klasse blir definert ut fra deres sosiale relasjoner i forhold til andre klasser innen produksjonssfæren. Det kan også nevnes at det er forsøkt å kombinere elementer i de to tradisjonene.

\section{Valg 1. Basis for klasse - empiriske vurderinger - sosial klasse eller yrkesklasse?}

Grunnlaget for de fleste yrkesinndelinger i norsk samfunnsforskning er Nordisk Yrkesklassifisering (NYK). Denne yrkesgrupperingen blir også brukt i all offentlig statistikk. Den er i utgangspunktet en detaljert fortegnelse over flere tusen yrker som finnes i Norge. Hvert yrke har et femsifret nummer som det identifiseres med, men det er imidlertid sjelden at en har opplysninger om så mange yrker. Yrkene kan slås sammen til yrkesgrupper, yrkesområder eller yrkesfelter.

Yrker kan i hovedsak klassifiseres eller grupperes på to måter. Enten plasserer en yrkene langs en endimensjonal skala, der hvert yrke tilordnes en bestemt verdi, for eksempel mellom 0 og 100. Yrkesprestisje er et eksempel på en slik skala. Alternativt kan yrkene inndeles $\mathrm{i}$ et mindre antall grupper på et eller flere kjennetegn, som for eksempel arbeidsoppgavens art, grad av beslutningsmyndighet, krav om utdanning eller lignende. Hvorvidt en bør foretrekke mål for sosioøkonomisk status eller yrkesprestisje er gjenstand for debatt. I praksis viser det seg at korrelasjonene mellom dem er ganske høy. Derfor kan det ofte være et spørsmål om hensiktsmessighet når det gjelder hvilken yrkesklassifisering en velger å bruke. ${ }^{1}$

De fleste klasseinndelingene som benyttes i Norge anvender også yrkesopplysninger fra NYK, men kriteriene som brukes er ikke de samme som i yrkesinndelingene. Klasseinndelingene trekker først og fremst inn ansettelsesforhold, men størrelsen på gårdsbruk, utdanning, inntekt eller opplysninger om deltakelse i beslutninger i arbeidslivet blir også brukt. Mange av disse inndelingene er inspirert av marxistisk teori, men de forutsetter ikke fortrolighet med dette for å kunne anvendes. De er på mange måter lik yrkesinndelingene, og har også felles formål i det å avgrense brede samfunnsgrupper på basis av yrkes og arbeidsforhold.

\footnotetext{
${ }^{1}$ For en nærmere oversikt over ulike yrkesgrupperinger kan det henvises til Engelstads rapport om "Skalaer, mål og indikatorer". Når det gjelder yrker blir Skredes skala for sosioøkonomisk status, Treimans internasjonale skala for yrkesprestisje, Vangsnes' sosialgruppeinndeling, Tvedes, Lafferty og Knutsen, Galgerud og Lindbekk sine yrkesgrupperinger, Baadshaug og Eeg-Henriksens yrkesgruppering etter kjønnsdominans og Colbjørnsens yrkesklassifisering etter åpne og lukkete ansettelsesforhold beskrevet og evaluert.
} 
Tatt $\mathrm{i}$ betraktning hvor ulike sosialklassemodellen og yrkesklassemodellen er teoretisk, peker flere studier på at de er forbausende like i sin empiriske forklaringskraft. Mange er skeptiske til å validere konkurrerende teoretiske begrep, som for eksempel klasse, ved å sammenligne deres empiriske forklaringskraft eller korrelasjon med ulike avhengige variabler. Det finnes imidlertid en empirisk bedømming som er basert på at en sammenligner kategorier hvor de to rivaliserende teorier er enige, med kategorier hvor de to rivaliserende teorier er uenige. Lodden (1995) har sammenlignet Goldthorpe/Eriksons klassemodell, Wrights dominansmodell, Statistisk Sentralbyrås sosioøkonomiske klassifikasjon, Skredes skala og Treimans internasjonale skala for yrkesprestisje. Modellene sammenlignes empirisk, med hensyn til utdanning, inntekt, autonomi, klasseidentifikasjon og politisk stemmegivning. Goldthorpe/Eriksons modell og SSBs klassifikasjon ble foreslått som de beste, men det ble understreket at forskjellene mellom de ulike modellene på mange områder var overraskende små.

\section{Valg 2. Enhetene i analysen - teoretiske vurderinger - familie eller individ}

Hva er passende enheter å inkludere i analysen; individet, familien eller husholdet?

Plasseringen av kvinner har i en årrekke vært et teoretisk og empirisk diskusjonsområde innen klasseanalysen. I en artikkel fra 1973 pekte Acker på at nesten alle empiriske klasse- og lagdelingsstudier var basert på familien som analyseenhet. Den status eller klasseposisjon som hovedforsørgeren, vanligvis en mann hadde, ble uten videre antatt å reflektere klasse- eller statusposisjonen for familien som helhet. I det som betegnes som det konvensjonelle synet blir kvinners klassetilknytning bestemt av enten farens, ektefellens eller samboerens klassetilhørighet. Kvinners klassetilhørighet bestemmes uavhengig av egen yrkesstatus, og familien eller husholdets sosiale posisjon er uberørt av kvinnens yrkesposisjon uansett om kvinnen er hjemmeværende, sekretær eller professor. Disse forutsetningene reflekterer delvis det kjønnsdelte arbeidslivet $\mathrm{i}$ vestlige, avanserte kapitalistiske samfunn på midten av det tjuende århundre, med klare skiller mellom lønnet og ulønnet arbeid og mellom marked og husholdning.

Klasselokalisering av individer uten inntektsgivende arbeid, som for eksempel arbeidsledige, pensjonister, husmødre og studenter har alltid vært problematisk for de modellene som baserer seg på et klassebegrep knyttet til yrke. En praktisk løsning har derfor vært å ta familien som enhet for analysen. Hvor relevant dette er avhenger av hvor utbredt to-inntektsfamiliene er i samfunnet. For Norges vedkommende tyder mye på at èn-inntektsfamilien sjelden har vært særlig utbredt. Den funksjonsdelte kjernefamilien utgjorde bare ca. $10 \%$ av befolkningen i slutten av forrige århundre, og befant seg først og fremst i embetsfamilier og den velstående delen av borgerskapet. Denne familietypen hadde riktignok sin storhetsperio- de fra midten av 1930-tallet til midten av 1960-årene. Etter dette har utviklingen gått raskt, og gifte kvinners yrkesdeltagelse har økt sterkt. I 1995 var kvinner medansvarlig for den økonomiske forsørgelsen i ca. 96\% av alle familier i Norge.

Den konvensjonelle tilnærmingen til klasseanalysen er særlig kritisert fordi kvinners yrkesdeltagelse ignoreres. Dette er en berettiget kritikk, og det er all grunn til å utvikle nye modeller og inkludere både menn og kvinner i analysen. Dette fordi kvinners yrkesaktivitet vil fortsette og er dessuten underbygget juridisk av blant annet likestillingslovgivning. Kvinner har etter hvert lang yrkeserfaring, flere forfremmes, yngre kvinner tar lengre utdanning, periodene med barnefødsler blir kortere og følgelig avbruddene i yrkeslivet færre. Klassemodeller som ignorerer kvinner gir derfor kun et bilde av det mannlige klassesamfunnet. De gir dermed et inadekvat og begrenset bilde av både yrkesstrukturen, klassestrukturen, klassemobiliteten og klassebaserte ulikheter.

Kritikken er også berettiget på grunn av at den ikke fanger opp skillelinjer i samfunnet knyttet til offentlig versus privat sektor eller kjønnssegregeringen i arbeidsmarkedet. Kvinner befinner seg ofte i andre yrker enn menn. Dette betyr at det finnes kryss-klassefamilier, det vil si familier hvor ektefellene er i posisjoner med ulike klasseinteresser, for eksempel der mannen er ingeniør og kvinnen arbeider som hjemmehjelp. Disse familiene utgjør en stor analytisk utfordring til den konvensjonelle strategien. Rent empirisk er dette også en utfordring. En ting er at dersom det finnes mange slike kryss-klasse-familier kan de ikke uten videre utelukkes $\mathrm{i}$ analysen. En annen ting er hvorvidt feilplassering av kvinner ut fra objektive kriterier også innebærer feilplassering med hensyn til subjektive forhold, som for eksempel klassebevissthet eller klasseidentifikasjon.

Hvis yrkesaktive ektepar har relativt like posisjoner $\mathrm{i}$ arbeidslivet vil disse familiene være helt eller delvis klasse-homogene. Selv om det er en tendens til at ektepar har samme eller relativt lik sosial prestisje basert på deres yrke, er det blitt påpekt at klasse og yrke bør sees på som to atskilte analytiske begreper. Det å ha samme status basert på yrke er ikke nødvendigvis det samme som at de har samme klasseposisjon basert på for eksempel dominansrelasjoner. Og omvendt, en og samme klasse kan inneholde en rekke ulike statusgrupper. Dersom familiene er klassehomogene vil hvertfall ikke den konvensjonelle strategien tillegge kvinnene feilaktige objektive interesser. Ut $i$ fra marxistisk teori preges da ektefellene av like erfaringer og har dermed de samme klasseinteressene.

Når klasser defineres etter en ny-weberiansk modell som grupper med relativt like livssjanser blir det tilsynelatende mer logisk å bruke familien enn individet som analyseenhet, nettopp fordi individets livssjanser er sterkt knyttet til familiestatus. Goldthorpe, og andre med ham, hevder at kvinnenes livssjanser $\mathrm{i}$ klassesamfunnet hovedsakelig bestemmes av menn, 
enten deres far eller ektemenn som gjennom sine posisjoner preger kvinners klassespesifikke oppvekstvilkår, livssjanser eller livsvilkår. Derfor hevder de at kvinners klasseidentitet er preget av deres menns klassetilknytning som familiens hovedforsørger, snarere enn deres egen posisjon i yrkeslivet. Empiriske analyser viser også at ektefellers posisjoner har innflytelse for hverandres klasseidentitet, og det er fremdeles slik at menns posisjon i større grad preger kvinners identitet enn omvendt. Derfor er det svært viktig å trekke inn begge ektefellenes klasseposisjon i arbeidslivet, slik at det blir mulig å belyse empirisk hvordan ektefeller påvirker hverandre både i klasse-homogene og klassehetrogene familier. Mange er enige $i$ at valget av enhet i stratifikasjons- og klasseanalyser bør avhenge av hva man skal studere.

Den feministiske kritikken mot konvensjonell klasseanalyse har blant annet ført til at et stort antall studier benytter individet som enhet $i$ analysene. Dermed er kvinner og deres yrkessituasjon blitt synliggjort, kjønnsulikhetene i arbeidsmarkedet er blitt avdekket og vår forståelse av de mekanismer som ligger bak kvinners ufordelaktige stilling i arbeidsmarkedet har blitt vesentlig forbedret.

\section{Valg 2. Enhetene i analysen - empiriske vurderinger - enkle eller multiple indikatorer}

Eksistensen av økt antall eneforsørgere i alle vestlige land, som for eksempel skilte kvinner med barn, eller familier bestående av en arbeidsledig mann og en yrkesaktiv kvinne, har gjort at flere representanter for konvensjonell klasseanalyse har innsett at disse må inkluderes i analysene. Det er derfor blitt argumentert for at en families yrkestilknytning må avgjøres av klassen til mannen eller kvinnen, avhengig av hvem som har den mest dominerende tilknytningen til arbeidslivet. Eriksons dominansmodell er et eksempel på dette. Denne modifikasjonen kan sees som en bevegelse fra et patriarkisk syn til en empirisk løsning, og den gir hvertfall muligheten for at kvinner kan være den personen i familien som influerer sterkest på familiens forbruksmønster, livsstil, inntekt eller status - og kvinnelige eneforsørgere blir heller ikke ekskludert fra analysen hvis det ikke finnes menn i hennes familie eller husholdning. Fordelen med dominansmodellen er at det er yrkesposisjonen og ikke kjønn som er det avgjørende $\mathrm{i}$ bestemmelsen av familiens klasseposisjon. Kvinners klasseposisjon endres heller ikke nødvendigvis ved giftemål ved bruk av denne modellen. En slik strategi er imidlertid heller ikke uproblematisk. I praksis vil det fortsatt være menn som blir familiens overhode. I tillegg betyr det at kvinner inkluderes i klasseanalysen på menns premisser, fordi deres yrke plasseres inn $i$ et yrkesskjema konstruert ut fra informasjon om menns arbeids- og markedssituasjon.

Birkelund (1993) hevder at sosiale klasser verken består av familier eller individer, men av individer som lever i familier. Hun har gjennom sine studier vist at det er viktig å operere på ulike analysenivå i klasseanalysen. Valg av analyseenhet vil følgelig være avhengig av både perspektiv og problemstilling, og er verken et prinsipielt spørsmål slik det ofte blir fremstilt, eller et empirisk spørsmål slik konvensjonelle klasseanalytikere nå argumenterer for. Noen ganger vil det være naturlig å bruke individet som analyseenhet som for eksempel i analyse av arbeidslivsrelasjoner, i andre tilfeller familien, for eksempel $i$ analyse av sosialisering eller forbruksmønster. Dersom familien skal brukes som enhet, bør imidlertid analysen bygge på informasjon om både kvinners og menns klasselokalisering i arbeidslivet. Da kan også ulikheter innad i familien mellom ektefellene problematiseres.

\section{Valg 3. Hvem skal inkluderes i analysen-teoretiske og empiriske vurderinger}

Skal man inkludere eller ekskludere økonomisk inaktive personer?

Valg nummer to og tre henger på mange måter sammen, de handler om hvem som skal være med i analysen. Dette er et problematisk valg fordi det eksisterer så mange ulike grader av økonomisk aktivitet. Økonomisk aktivitet er vanligvis delt $\mathrm{i}$ fulltid og deltid med varierende grenser. Videre er det flere varianter av økonomisk inaktive, fra de permanent inaktive til midlertidig inaktive osv.

Det har vært en utbredt praksis å ekskludere ubetalt husarbeid, og dermed er kvinner utelatt i mange analyser. En pragmatisk holdning til bare å bruke økonomisk aktive er at det blir lettere, man slipper å måtte ta stilling til hva man skal gjøre med de økonomisk inaktive. Et annet argument er at det gir mulighet for direkte sammenligninger, fordi overvekten av tidligere forskning ekskluderte økonomisk inaktive. En generell kritikk av studier som ekskluderer voksne økonomisk inaktive er at de gir et fordreid syn på klassestrukturen. Hvis man bare tar med økonomisk aktive, voksne med heltids arbeid $\mathrm{i}$ en studie ville for eksempel 58\% av den norske befolkningen blir ekskludert. Generaliseringer om klassestruktur og klasseforhold blir følgelig mindre valide når de er basert på små og urepresentative deler av befolkningen.

Økonomisk inaktive kan klassifiseres ut fra tidligere sosiale tilhørighet, hvis det er mulig. Siden pensjon er bestemt ut fra tidligere yrke lar dette seg gjøre for arbeidsledige, trygdede og pensjonister. Når det gjelder hjemmeværende eller studenter som aldri har vært yrkesaktive er det ikke så enkelt. Når det gjelder den første gruppen går diskusjonen på om man skal klassifisere etter hovedjobben eller etter siste jobb, eller om en skal skille mellom midlertidig og langvarig arbeidsledige, og at det da bare er de langvarig arbeidsledige som skal klassifiseres etter siste yrke. Andre igjen har klassifisert de arbeidsledige i en egen separat underklasse. Økningen av ungdom og andre som er i arbeidstreningsprogram viser at det er behov for en egen separat kategori for økonomisk status som omhandler denne gruppen. 
Et lignende problem finnes når kvinner som har avbrutt yrkesaktivitet på grunn av for eksempel omsorgsarbeid skal klassifiseres. Det er urimelig at bevegelser inn og ut av arbeidsmarkedet skal forandre klassetilknytningen både for individet og for husholdet. Det er hevdet at siste yrke er en god prediktor for kvinner i for eksempel fødselspermisjon, men andre hevder at når bare siste yrke er tilgjengelig så er det en dårligere indikasjon på klasseposisjonen enn om man tok utgangspunkt i det yrket kvinnen hadde før første fødsel.

Studier som bruker individmål og bare inkluderer økonomisk aktive må bestemme om de skal ha med eller utelukke deltidsarbeidende. Husholdsbaserte mål møter i tillegg problemet der det $\mathrm{i}$ husholdet er noen som arbeider heltid og noen deltid. Dominansmodellen legger hovedvekten på den som jobber heltid. Dette vil igjen i praksis si at kvinner ekskluderes. De har et poeng de som mener at kanskje ikke yrke er den rette basisen å bruke for klassetilhørighet for de som ikke er direkte involvert $\mathrm{i}$ arbeidsmarkedet?

\section{YRKE, UTDANNING OG INNTEKT}

De viktigste kriterier for ulikhet i den industrialiserte verden er økonomisk velstand, inntekt, utdanning, yrke, yrkesstatus og politisk innflytelse. Ulike livssjanser og livsstil resulterer i respektiv ulikhet, og det er dette som ofte er poenget å utdype i epidemiologiske studier.

Yrke, utdanning og inntekt er de tre indikatorene som hyppigst brukes i epidemiologien for å måle sosial ulikhet. Yrke, som diskutert i det foregående, kan være basis i klasse- og lagdelingsklassifiseringer og være et mål for sosiale relasjoner eller status og prestisje. Yrke sier også noe om utdannings- og inntektsnivå, og blir ofte brukt som utgangspunkt for sosioøkonomiske mål som for eksempel sier noe om folks ulike livsstil. Brukes yrke på denne måten sier det noe om sosial ulikhet.

En rent teknisk yrkesgruppering skiller seg derimot fra dette. Epidemiologiske og yrkesmedisinske studier og stressforskning viser imidlertid at det nettopp er de tekniske og fysiske sidene ved yrke, og de arbeidsbelastningene som følger med yrke, som er relevant for helse og sykdom. At yrke virker direkte på helse gjennom fysiske og psykososiale mekanismer er plausibelt. Men, å korrelere en teknisk yrkesklassifisering direkte med en sykdom er ikke en analyse av sosial ulikhet, fordi yrke er da definert helt uavhengig av rikdom, anseelse eller makt som er de sosiale ulikhetsdimensjonene.

Utdanning er ofte en forutsetning for å kunne inneha visse yrker eller oppnå et visst inntektsnivå. Derfor kan utdanning brukes som en proxy variabel på det økonomiske området. I klasse- og lagdelingsanalysen indikerer utdanning en rekrutteringsmekanisme, utbyttingsgrad, markedsressurser eller sosial anseelse. Omfanget av utdanning og viten som folk er i besittelse av påvirker også deres holdninger, adferd og praksis. Da influerer utdanning på for eksempel livsstil og sosialt nettverk. Dette kan representere Webers statusområde.

I epidemiologien er utdanning også relevant $\mathrm{i}$ betydningen av mestringsevne eller problemløsningsevne. Dette er av stor betydning for helse og sykdom. Mestring er et begrep som knyttes til mennesker som bevisste, aktive og målrettede aktører, og dermed kan det være mulig å forhindre sykdom. Man kan handle medisinsk riktig hvis en blir syk, eller beherske en tilværelse med en kronisk sykdomstilstand.

I klasse- og lagdelingsanalysene reflekterer inntekt markedsressurser, belønning for yrkesprestasjoner og materiell velstand. Inntektsforskjeller influerer også på mulighetene for utdanning og tilgang til ulik livsstil, prestisje eller makt. Det at inntekt er negativt korrelert med helse og sykdom er et tankekors i velferdsstaten Norge. Vi har en relativt høy jevnt fordelt inntekt, og et sikkerhetsnett som skal sørge for at ingen faller under et fysiologisk eksistensminimum. Sosiologen Peter Townsend har introdusert begrepet om relativ deprivasjon, og implisitt i dette begrepet ligger inntekt. Selv om vi i vestlige land har høy levestandard så har vi relative materielle forskjeller som kan føre til ulikhet $\mathrm{i}$ helse og sykdom. Arbeidere har dårligere arbeidsmiljø, er mer utsatt for støy og miljøforurensninger eller har mindre muligheter til rekreasjon. Slik sett har Norge fortsatt relativ materiell fattigdom.

Sosial deprivasjon er et annet begrep. Vi har som kjent ikke bare fysiologiske behov, men også sosiale behov. Manglende tilfredsstillelse av dette kan også være helseskadelig. Det finnes omfattende sosialepidemiologisk litteratur som underbygger dette og kan forklare mange av problemene til de marginaliserte gruppene. Sosial isolasjon på grunn av dårlig råd forklarer imidlertid ikke hvorfor sykepleiere, som klassifiseres som funksjonærer på mellomnivå, har høyere dødelighet enn overleger, som klassifiseres som funksjonærer på høyeste nivå.

Når yrke, utdanning og inntekt brukes i epidemiologiske studier benyttes ofte varierende skalaer for disse, og det kommer ikke alltid klart fram hvorfor disse målene ble benyttet. Var det fordi forskeren mente at av alle mulige mål for sosial ulikhet så var utdanning den beste prediktoren, var variabelen viktig i seg selv eller rett og slett det enkleste målet å bruke? I tillegg til å konseptualisere klassebegrepet er det også andre spørsmål man bør stille seg. For eksempel hva skal sosial klasse brukes til, er det en årsaksvariabel eller en proxy variabel, en confounder eller en 'just in case' variabel? Passer de sosiale målene med studiepopulasjonen eller i forhold til andre studier? Er de sosiale målene relevante til tidsperioden som studeres? Er målene reliable og valide? Skal man bruke ett eller flere mål for sosial ulikhet? Skal man bruke diskrete eller kontinuerlige variabler? 


\section{AvsLutning}

Det å fokusere på sosial ulikhet $\mathrm{i}$ forskning om variasjoner i helse, sykdom og dødelighet kan føre til en bedre forståelse av komponenter i årsakskjeden mellom sosial tilhørighet og risiko for sykdom. Ofte er sosial tilhørighet et utgangspunkt som kan føre til en bedre forståelse, eller til å finne viktige spor $\mathrm{i}$ en undersøkelse om årsakene til sykdom. Empirisk forskning på sosial ulikhet bør derfor bli mer omfattende i datainnsamlingsfasen og bedre til å rapportere om forskningsmetodikk. Dette ville være til hjelp i sekundæranalyser. Det er behov for data om både respondenten og andre personer $\mathrm{i}$ husholdet, uansett om de er økonomisk aktive eller ikke. I tillegg til opplysninger om utdanning, yrke og inntekt er det også behov for utfyllende data om livsstilfaktorer. Mer kvalitative data er en forutsetning for å komme nærmere hvilke mekanismer og prosesser som påvirker sosial ulikhet $\mathrm{i}$ helse. For å få mer innsikt i marginale kategorier er dette også nødvendig.

\section{KILDER}

Acker, J. (1973) Women and social stratification: A case of intellectual sexism. American Journal of Sociology, vol. 78.

Birkelund, G. (1993) Klasse, kjønn og sosial identitet. Sosiologisk tidsskrift, vol. 1.

Colbjørnsen, T., Birkelund, G.E., Hernes, G., Knutsen, K. (1987) Klassesamfunnet på hell. Oslo: Universitetsforlaget.

Duke, V., Edgell, S. (1987) The operationalisation of class in British sociology: theoretical and empirical considerations. British Journal of Sociology, vol. 38.

Dahl, E. (1994) Sosial ulikhet i helse: Artefakter eller seleksjon? Oslo: FAFO-rapport 170.

Elstad, J.I. (1982) Et gjennombrudd for empirisk samfunnsforskning? Materialisten, 4/1982: 75-91.

Elstad, J.I. (1992) Et klassebegrep for 90-årene? En kritisk oversikt over tre sosiologiske klasseteorier. Tidsskrift for samfunnsforskning, 33 (1): 3-26.

Elstad, J.I. (1995) Sosial klasse i helsestatistikk og forskning. Tidsskrift for Den norske laegeforening, 115: 502504.

Engelstad, F. (1983) Skalaer, mål og indikatorer. En oversikt over forskjellige måter å gruppere data om det norske samfunnet. Oslo: Institutt for samfunnsforskning, rapport 5/83.

Erikson, R. (1984) Social class of men, women and families. Sociology, vol. 18.

Erikson, R., Goldthorpe, J.H. (1992) Individual or family? Results from two approaches to class assignment. Acta Sociologica, vol. 35 .

Goldthorp JH., Marshall, G. (1992) The promising future of class analysis: A response to recent critiques. Sociology, vol. 26.

Lodden, U. (1995) Klasse- og lagdelingsanalyse: en sammenligning av ulike sosialgruppeinndelinger. Bergen: Universitetet i Bergen.

Skrede, K. (1971) Sosioøkonomisk klassifisering av yrker i Norge, 1960. Oslo: INAS rapport nr. 71-1.

Skrede, K. (1986) Den Norske kvinnerevolusjonen: kvinners arbeid 1975-85. Oslo: Universitetsforlaget.

Wright, E.O., et al. (1989) The Debate on Classes. London: Verso. 